\title{
Joseph Stiglitz
}

In 2001, Joseph Stiglitz was awarded the Nobel Prize for economics. In 2002, he published an article in the Review (Vol.141, No. 1-2) entitled "Employment, social justice and societal well-being" in which he proposes that the purpose of economic activity is to improve the well-being of individuals, and that employment is essential to this well-being. In this regard, his description of the negative effects of unemployment echoes that given in the abovementioned article by Amartya Sen on unemployment in Europe. While such assertions may seem obvious, economic policy often runs counter to the interests of workers. In addition to generalized market imperfections, the under-representation of workers and the infatuation with neoclassical policies purporting to separate efficiency issues from equity, Stiglitz blames the fact that neoclassical economics treats labour like a commodity. It is up to governments - and more generally to the international community - to ensure that development does not become merely a matter of capital accumulation. Thus, 80 years later, he denounced disregard for the first of the ILO Constitution's General Principles: labour is not a commodity.

And then came the crisis in 2008. In 2009, Stiglitz published another article in the Review (Vol. 148, No. 1-2) entitled "The global crisis, social protection and jobs". This article, which is reproduced here, notes that the policy responses to the global financial meltdown and the collapse of aggregate demand had largely been driven by domestic interests. Resurgent protectionism, bank bail outs and national stimulus packages were distorting competition and incentives, to the detriment of developing countries, much-needed spending on social protection and, ultimately, rapid global economic recovery. Warning against underestimation of the job-destruction potential of the current crisis, Stiglitz argues for a truly global stimulus package, together with a rethink of economic paradigms and regulatory policies, financial assistance to developing countries, a less constraining IMF, and stronger social protection as an automatic stabilizer of economies. 


\title{
The global crisis, social protection
} and jobs

Joseph STIGLITZ

Originally published in International Labour Review, Vol. 148 (2009), No. 1-2, pp. 1-13.

\begin{abstract}
he most engrossing topic of the day is obviously the question of the global economic crisis. This article begins by addressing some of the broader issues, and then turns to particular aspects relating to decent work and social protection.
\end{abstract}

\section{A global crisis "Made in the USA"}

The current crisis is touching every country in the world, including the developing countries. For a while there was a myth that there would be decoupling - that the crisis, which began in the United States, would leave Europe and the developing countries untouched. It is very clear that this is not the case. Globalization has meant that the world economy has become integrated, that there cannot be a major downturn in the world's richest country without implications for every other country.

Moreover, the way globalization has been managed allowed the United States to export its toxic mortgages all over the world. Had the rest of the world not bought as many of them as it did, the downturn in the United States would have been much worse. This crisis has a very clear "Made in the USA" label on it. Not only did the United States export its toxic mortgages, but it also exported the deregulatory philosophy that allowed others to buy these toxic mortgages and ensured that regulators abroad did not stop it.

The economic downturn is affecting even those developing countries which had succeeded in managing their economies well, those that had sound monetary policies and regulatory frameworks. In fact, as we looked at the monetary and regulatory policies of various countries, one of the observations made by the Commission of Experts of the President of the United Nations

Responsibility for opinions expressed in signed articles rests solely with their authors, and publication does not constitute an endorsement by the ILO. 
General Assembly on Reforms of the International Monetary and Financial System, which I am chairing, was that some of the developing countries really did a much better job than the United States. The United States should go and study what good central banks do, in India and elsewhere, because they actually did avoid the excesses that marred American financial markets. When American banks wanted to sell complex, risky derivatives, one of the central bankers in South-East Asia said, "Can you explain that?" They said, "No, we can't." She responded, "Well, if you can't explain it, you can't sell it." Thus, they were protected against the ravages of the derivatives which have had such a negative effect on the United States and Western Europe.

There are multiple channels through which this crisis is affecting all the countries of the world. The most direct channel through which it began was, of course, financial markets. Financial flows, which were so strong in good years, are now reversing, meaning that access to finance is becoming a problem in many developing countries. A dramatic fall in the flows to developing countries is projected; in some cases, there may actually be reverse capital flows. Another channel is the unprecedented fall in exports. The declines are of a magnitude that no one ever expected to see. Furthermore, there are impacts through remittances and labour flows. Inevitably, when employment goes down, immigrant labourers are among those first hurt. In the United States, the banks that are getting bail-outs were told that they could not hire immigrant workers, so there have been restrictions on hiring workers from abroad, no matter how qualified they are. Job offers have had to be rescinded, and immigration is being affected.

\section{Resurgent protectionism and other distortions of trade and investment}

In November 2001, during the last global economic downturn, Mr Juan Somavia, the Director-General of the ILO, made a statement in which he decisively rejected protectionism. This time again, we have made that statement, but it has not been followed through. Protectionist measures are being taken all over the world. It was a good thing that the members of the G-20, at their meeting in November 2008, committed themselves not to engage in protectionism, but it is a sad thing that they did not honour their promise. The protectionism that has occurred has been both direct and indirect, intentional and unintentional, but it has been pervasive. For example, the United States' stimulus package included a "Buy American" provision. Clearly, this is a violation of the spirit of "no protectionism". The Government then said this provision would be suspended to the extent that it violates international World Trade Organization (WTO) agreements. That sounded good, but the WTO agreements on government procurement are in fact between the United States and other advanced industrial countries. The message behind that language was in effect: "We will continue to buy goods from the other advanced industrial countries, from the 
rich countries, but we will discriminate against goods from poor countries." This is even more invidious than an across-the-board protectionist policy.

The spirit of international trade agreements recognizes that tariffs are a trade distortion, but so are subsidies. That is why there are general restrictions on subsidies except in agriculture - and we know that agricultural subsidies help to create an unlevel playing field and distort the patterns of trade. During the current crisis, however, the advanced industrial countries have been providing massive subsidies to their enterprises, including their financial enterprises. Thus, even if there may once have been a level playing field, no one can claim that this is so today. How can a bank, a financial institution, or an automobile company from a developing country compete with an automobile company or financial institution from the United States that received tens of billions of dollars of assistance?

It is not only the financial institutions that have received aid. The fact is that the United States and Western Europe have signalled to big companies that if they have problems, they will be bailed out. Or at least, they may be bailed out. This has changed the propensity of these companies to undertake risk, because if they undertake big risks and lose, taxpayers pick the losses up. If they win, they get the profits. The level playing field has thus been destroyed for years to come, and we should recognize that the old trade and investment regime has been - intentionally or unintentionally - altered in a fundamental way.

Take the issue of guarantees provided to banks. Even if the developing countries reciprocated and provided guarantees to their banks, symmetric policies can have asymmetric effects. A guarantee by developing countries to their banks does not have the same weight as a guarantee from the United States. This is part of the reason for the anomaly of reverse capital flows. Money is going to the United States, which is the source of the original problem. The United States caused the global financial crisis by bad regulation and bad financial practices, but money is going into these bad financial institutions because the United States Government has provided a guarantee.

\section{A global crisis calls for global remedies}

Clearly, the current crisis has really altered the nature of global competition in profound ways, and we will need to rethink all the elements of the rules of the game in order to move forward. It is a truly global crisis, and within a globally integrated economy, a crisis of this kind can only be addressed globally.

We need a global stimulus package for the world economy, but the locus of decision-making remains at the national level. Thus, there is a disjunction between what is needed, which is global action, and the locus of decision-making, which is national. This is important because each country weighs its benefits and its costs, including the cost of things like the increase in the national deficit, as it looks at a stimulus package. The benefits each country looks at are the benefits only to its own economy, not the global economy. The result 
is that there will be insufficient global stimulus unless it is provided in a globally coordinated way.

To put it another way, in terms of macroeconomics, we usually talk about "multipliers": how much extra GDP is generated, or how many jobs are generated, by each dollar of government spending or stimulus? However, there is a very big difference between the national multiplier and the global multiplier, especially in small, open economies. Economists call this difference "leakage", whereby some of the money spent does not stay in the national economy. If all the money stayed in the economy, it would recirculate and keep boosting the economy. In an open economy, some of the money that is spent goes to other countries but stays within the global economy. We are not part of a galaxy, and we still trade only within the world, so the world is a closed economy. There are no leakages within the world, and the global multipliers are very large. As the global economy has become more integrated, the national multipliers have become relatively small, and the net result is that there will be an incentive not to have a large enough stimulus.

Furthermore, as each government thinks about how to design a stimulus package, the question it is asking is: "How can my country get the most benefit?" - not how the world can get the most benefit. It is focusing on stimulus spending that does not leak out but instead stays within the country. However, because governments are thinking nationally, the global impact is reduced, and the benefit from the stimulus is smaller than it otherwise would be. This is obviously of great concern because the current crisis is likely to be the deepest and longest economic downturn since the Great Depression.

\section{Social protection, automatic stabilizers and jobs}

The particular problem in the United States is that the stimulus is not only too little but also too late, and it has not been well designed. In looking at the size of the stimulus, one has to look at what else is going on in the economy. Are there automatic stabilizers or automatic destabilizers? When the economy gets weaker, spending on social protection and unemployment schemes should automatically go up, helping to stabilize the economy. However, at least in the United States and some other countries, one of the sad facts of the so-called reforms in recent decades is that we have been weakening these important automatic stabilizers. The extent of progressivity in tax systems has been lowered, and we have moved from defined benefit systems to defined contribution retirement systems, again weakening the automatic stabilizers of the economy and in some cases converting them into automatic destabilizers.

If one compares the situation when the United States had good social protection, with defined benefit pension programmes, and the situation that country has been moving into, with weak social protection, with defined contribution pension programmes: what has happened to most Americans? They have seen their retirement accounts devastated at the same time as the value of their house has fallen dramatically by $20-30$ per cent, in some cases 50 per 
cent. The money that people put away to pay for the education of their children or for their own retirement has been wiped out. The country used to have a system that would protect them against these kinds of risks, but mistakenly it got rid of it.

As Americans see their savings and retirement accounts eroded, they will realize that they have to save more. In many ways, in the long run, this is a good thing for the American economy: the household savings rate had gone down to zero, and that was not sustainable. In the short run, however, it is a real problem. Already, there are indications that the savings rate in the United States may have gone from zero all the way up to 5 per cent, and it is still increasing. This is a massive change in aggregate demand: if people are saving more, they are spending less. It is this reduction in spending that is weakening the global economy, leading to a lack of aggregate demand.

The weakening of the United States' automatic stabilizers is compounded by the further problem that the states have automatic destabilizers. They have balanced budget frameworks, which means that when revenues go down, they either have to cut back expenditures or raise taxes. The magnitude of these destabilizers is enormous. A few months ago, before the downturn got much worse, it was estimated that the shortfall in state taxes would be around US\$150 billion a year. Now it is probably much larger than that, perhaps US\$200 billion a year. This means that over a two-year period, the negative stimulus from the reduction in state revenues offsets 40 or 50 per cent of the total federal stimulus. From this perspective, one realizes how small the United States stimulus package really is - and that it clearly is not up to the task lying ahead.

To put it another way, in terms of jobs, the stimulus package was supposed to create or save about 3.6 million jobs. However, the United States has already lost upwards of 2.5 million jobs, and it is still losing 600,000 per month. This rate is likely to continue. Meanwhile, there are almost 2 million new entrants into the labour force every year. Thus, at this juncture, there is already a job shortfall of 5 million, and there will be a shortfall of another 2-3 million jobs over the next two years. The creation or saving of 3.6 million jobs is inadequate relative to the need. By 2010, there will be a very large job deficit in the United States. And I think these problems are being replicated, in some cases even more dramatically, in other countries around the world.

\section{The crisis and the developing world}

That brings me to looking at this crisis and the stimulus from the perspective of the developing countries. There is agreement that we need to have a global stimulus, but countries in the developing world do not have the resources to finance a stimulus package. The United States can spend US\$700-800 billion on a stimulus package, but most developing countries do not have the resources to do so. Unless they receive substantial assistance, these countries will not be able to engage in counter-cyclical policies, and there will thus not be a quick, robust recovery in a large part of the world that is being most affected by the 
crisis. These countries are innocent victims of bad regulatory policies in the United States, but they will not be able to engage in the counter-cyclical policies to save themselves unless something is done to help them. However, this is more than a question of responsibility or even humanitarianism; it is a question of self-interest, because there cannot be a robust recovery for the global economy if there is a significant part of the world that remains weak. It is imperative that assistance be given.

The Commission of Experts of the President of the United Nations General Assembly on Reforms of the International Monetary and Financial System is going to recommend that at least 1 per cent of advanced industrial countries' stimulus packages be allocated to developing countries. We should realize how small the numbers are: 1 per cent of a US\$700 billion package is US\$7 billion divided among the developing countries. It is not going to be enough, but it is better than nothing. The real point is that we have to explore a whole variety of innovative ways of bringing finance to the developing countries, and in the Commission's extended report, we will develop several ideas on how this might be done.

However, there is another problem, in addition to the lack of resources: the lack of policy space. If we go back to 1997-98 and the last financial crisis in East Asia, the IMF came to the help of the countries affected, but the assistance it provided came with conditions which made the downturns worse. The downturns became recessions, and recessions became depressions.

Some people might say that we will not have another Great Depression because today we know what to do and are so much smarter than we were in the 1930s. We should remember that, a decade ago, we were almost as smart as we are today, but the IMF and the United States Treasury went into Indonesia, gave advice about what to do with its financial system, and managed to destroy it. They imposed conditions that led to a deep depression in Indonesia: the unemployment rate in the central island of Java went up to 40 per cent. Anybody who thinks we are so smart today that we can avoid a depression should remember what happened in Java just a decade ago. Some of the same people who were in policy-making positions then may still be in policymaking positions today. Maybe they have learned their lesson, but maybe they have the same mental framework. We do not know, but we should obviously be concerned.

What happened ten years ago has another important implication. Because the countries in East Asia were so deeply affected by the IMF's mismanagement of these crises, many countries in that region - and, actually, many countries all over the developing world - have said they would never let this happen to them again. I was talking to the Prime Minister of one of the countries and he said, "We were in the class of '97. We learned what happened if you do not have enough reserves." The class of '97, and those who studied the lessons of the class of '97, have accumulated huge amounts of reserves, in the trillions of dollars. That is good for them and means that they are more protected. However, this presents a problem for the global economy because 
these people are receiving income which they are not spending. It is like burying income in the ground, which is exacerbating the lack of global aggregate demand. The lack of global aggregate demand is, in a sense, one of the fundamental problems underlying this crisis.

\section{Market failures and the role of government}

I think it is important, as we think about this crisis, to keep in mind the underlying problems. At the beginning of the crisis, a reporter asked President Bush what the problem was. His reply was, "Well, we built too many houses." It was true that we had built too many houses, but market economies are not supposed to build too many houses in the wrong places and beyond people's ability to afford them. The question we need to ask is: why did the market economy fail? People are now saying that there was excessively lax monetary policy and weak regulation. But then one has to ask, why were there these excessively lax monetary policies and weak regulation? Unless we ask those questions, we will not understand what to do about the current crisis.

One of the reasons that there were lax regulations was the misguided economic philosophy that said unfettered markets are the best way of running an economy, since markets are self-adjusting. Fortunately, almost everybody recognizes that this market fundamentalist view is wrong. Even Alan Greenspan, the former Chairman of the Federal Reserve, who is viewed as the high priest of market fundamentalism, has said, "I made a mistake." He learned this lesson at a great cost to everybody in the world, but at least he learned it. Some people have not quite learned. Markets are not self-regulating; there is an important role for government to try to make the market economy work. Markets are at the core of a well-functioning economy, but, by themselves, they are not enough. There needs to be a balance between the role of the market and the role of the government. Understanding when markets work and when they do not, and the limitations of markets as well as the limitations of government, is an essential part of developing appropriate policy frameworks.

The second question is why monetary policies were so lax. Why did Greenspan create a bubble? Again, there is a very simple answer: in the absence of lax monetary policy, there would have been insufficient aggregate demand in the United States and in the world. Greenspan allowed this in order to keep the American economy going. But why was there insufficient aggregate demand? In a globalized economy, we can only really answer these questions at the global level. Again, there are two answers. One is that, over the past 30 years particularly, there has been an increase in inequality. In effect, we have been transferring money from the poor to the rich, from people who would spend the money to people who do not need to spend the money, and the result of that is weaker aggregate demand.

The United States thought it could solve the problem: Americans who had no money were told to keep spending as if they had it. They enjoyed it for a while. A massive debt finance bubble enabled them to continue to 
spend. The richest country in the world was living beyond its means. When the United States was criticized, the Secretary of the Treasury said that the world should be thankful, because if Americans were not spending so much, the global economy would be weak. There was a sense in which he was right, but if it is true that the global economic system requires the richest people in the world to spend beyond their means, there is a fundamental flaw in the global economic system.

The problem is that the system is now broken, because it was based on American consumers spending beyond their means by borrowing and borrowing and borrowing; it was based on a bubble and house prices that were out of line. But the bubble has broken, and people now know they cannot continue to finance consumption in this way. One might say that the engine of global economic growth has been taken away.

Global inequality was one of the reasons that monetary policy was weak, but the other reason was the massive build-up of reserves that countries engaged in to protect themselves from having to turn to the IMF in case of economic volatility.

The reason I emphasize these more fundamental problems is that in the current discussions in the G-20 and other forums there is a lot of focus on trying to fix the regulatory system and a lot of attention to providing some shortrun stimulus. The question is, what is going to happen in two or three years' time? What is going to replace the sources of aggregate demand that fuelled the global economy in the period 2003-07, or even before that? We have gone from one bubble to another, from one unsustainable basis to another unsustainable basis, and unless we make more fundamental reforms, we will not be able to return to sustainable, robust economic growth. That is why I have tried to emphasize here some of the more fundamental problems underlying the current crisis.

\section{Competing paradigms, aggregate demand and wages}

I now turn to some of the underlying ideas and economic paradigms, which are important in order to understand the requisite policy responses. For the past several decades, there have been two paradigms that have been waging war with each other for the hearts and minds of people all over the world. One was the "market-fundamentalism" model, which I have referred to above, based on rational individuals with rational expectations, acting in perfectly competitive markets with profit-making competitive firms. The view was that unfettered markets were sufficient to ensure economic efficiency. The best role for government was a limited one, and somehow the benefits of the growth that this would engender would trickle down to everybody in society.

The other model was based on a set of ideas that has many sources and many strands. I will pick up one of them, emphasized by Keynes, which held that markets do not always work well or self-correct. After all, the Great De- 
pression did happen. There are two separate strands of Keynesian economics, one of which has been more influential but, unfortunately, largely wrong. It goes back to John Hicks and was disseminated most effectively by Paul Samuelson. This strand argued that the problem in the market economy was rigid wages, and that if it were not for wage rigidities, the economy would work in the way that classical economics predicted: markets would clear, everything would be fine, and Adam Smith would be in heaven. (Yet, Adam Smith actually understood Adam Smith much better than his modern descendants. He understood that markets do not always work well. He understood the importance of competition in ensuring efficiency, but that firms always try to restrict competition, and that you need to have competition. But the modern descendants of Adam Smith only read the parts of Adam Smith that they like.)

Modern economics explains why that tradition of Adam Smith was wrong. My own work on asymmetric information - simply the notion that some people know things that other people do not - showed that the reason why the invisible hand of the market often seems invisible is that it is not there. Markets are not, in general, efficient. This important idea is a very simple one, but it has not been taken fully on board by those who believe that markets are always efficient.

Many adherents of the rigid-wage Keynesian view argued for what was called the neoclassical synthesis, which said that the economy had two regimes, one in which things worked perfectly and in which Adam Smith was right, and another regime in which there was unemployment. All that was required was to ensure the economy was at full employment in order to ensure that markets work perfectly.

This conclusion is not based on economic science. It is neither a theorem nor an empirical "finding". It is an article of faith. A moment's reflection suggests that the underlying logic is very peculiar. It is much more reasonable to say that a complete breakdown of the economy, like we are seeing today and saw in the Great Depression, is symptomatic of a market failure so large that it cannot be ignored. Even market advocates say that something is wrong today. There are many other circumstances where markets are not perfectly efficient, where things are not working well, but the failures are harder to detect or predict. What we are seeing is the tip of the iceberg, but underneath there are smaller market inefficiencies on a massive scale that we ought to be aware of. In my own work I have tried to expose a number of these.

The implication of the Keynesian rigid-wage theory was very invidious but very pervasive: if rigid wages are the reason the economy is not working as well as Adam Smith said it should, what is the solution? Get rid of the rigid wages, and let labour markets be more "flexible". That has been the basis of a whole set of doctrines undermining job protections and labour rights.

Another strand that has grown out of Keynes, which I believe is much more fundamental, is due to Irving Fisher and Hyman Minsky (who has become much more fashionable). Much of my work during the past quartercentury has been in this tradition. Part of the motivation of our work was a 
simple observation: wages are not rigid. In the Great Depression wages fell by about one-third. How can anyone say that wages are rigid when they are falling, and by that amount?

The problem that Keynes recognized was that wages can be too flexible. Indeed, when wages fall, people's income falls and their ability to demand goods falls as well. Lack of aggregate demand was the problem with the Great Depression, just as lack of aggregate demand is the problem today. Imposing more wage flexibility can result in exacerbating the underlying problem of lack of aggregate demand.

Because of this current crisis, it is clear that almost no one today can believe in the rational expectations model and the efficient markets model. I say "almost no one" because there are a number of American academics who seem impervious to what has happened; no evidence will change their beliefs. They continue to believe that markets are fully efficient, even as unemployment goes up and as symptoms of irrationality become so evident. Yet once we reject the market fundamentalists, the question now is to try to understand the ways in which markets fail. The two contrasting Keynesian views - the rigid wage versus the problem of excessive flexibility - give two different ways of thinking about what is wrong and two very different policy responses.

Downward flexibility of wages or, to put it another way, deflation is a concern partly because of the loss of aggregate demand, as I have emphasized, but there is also another reason. The presence of deflation when debt contracts are nominal, not indexed, means that there will be problems of bankruptcy. Bankruptcy is costly and disruptive. Periods of deflation have historically been very difficult periods, with weak growth. Deflation was a problem in the United States and Japan in the late 1990s, and there is a worry about it being a problem today.

Bankruptcy is a concern because you can lose organizational capital if it is not well managed. If it is well managed, it is just a financial reorganization, which is an important point to realize. A lot of people today are excessively afraid of bankruptcy because it has been, in some instances, very badly managed. However, well-managed bankruptcies - as provided for under Chapter 11 of the United States Bankruptcy Code, for example - can maintain the integrity of the firms and be an effective way of going forward. One should not be afraid of it, though, to be sure, it is not costless.

The nature of the problem that we face today can be put in the following way. The people in the global economy have the same skills as before the crisis, and the machines and real resources are the same as before the crisis. The problem is that there is an organizational failure, a coordination failure, and a macroeconomic failure. We are failing to put to work these human and physical resources to produce output. What this highlights is the importance of economic policy and organization. It is not our resources that have disappeared. It is the way we organize those resources to create jobs and to create value. The challenge, in going forward, is to try to create the aggregate demand that will put those resources back to work. The question is: what kinds of policies and reforms are likely to do that? If we start asking that question, 
we realize that many of our policy frameworks in recent decades have been making things worse. I have already mentioned that we have weakened our automatic stabilizers by weakening social protection, and we have destabilized the economy by making wages more flexible rather than providing job security. We have created greater anxiety, which, in times like this, increases savings rates and weakens consumption. All of these so-called reforms have made our economic system less stable and less able to weather a storm.

\section{The lending crunch, bank bail-outs and the social consequences of skewed incentives}

In addition to the inadequacies of the stimulus, which I have already mentioned, another big problem facing the United States today in designing an effective recovery programme to address the economic crisis has been figuring out what to do with the failed banking and financial system. We all know what needs to be done, but it will be a challenge. We want to restart lending in a way that puts the least burden on the government deficit and debt. Unfortunately, the bank bail-outs have done just the opposite: hundreds of billions of dollars have been spent, increasing the national debt but with no increase in lending. If the United States had taken US\$700 billion and created a new bank, unburdened with the past, and allowed it to leverage 12 to 1 - which is very modest compared to the risky 30 to 1,50 to 1 , and up to 100 to 1 leverage that the banks being bailed out had - at just 12 to 1 that 700 billion would have created US\$8.4 trillion of lending capacity. That US\$700 billion could thus have been used to generate all the lending capacity required, including loans for small businesses and to maintain enterprises. The profits from the new bank would have paid back the Government. Instead, it was decided to spend the money in ways that protect some existing vested interests.

It is simple to understand what has happened: banks in the United States created some toxic assets. Some of them were sold to Europe, but a lot of them are still held back in the United States. The mistakes have been made, and a basic law in economics is to let bygones be bygones. The losses are there. The banks loaned on the basis of a bubble, and the bubble has broken. Nothing is going to change that. A lot of people, in the financial sector and elsewhere, want everyone to believe that somehow if there were just a restoration of confidence, the losses would disappear. I wish that they were right, but they are wrong. There was a bubble that was apparent at the time and is doubly apparent now. Now the question is: who bears the losses? This is close to a zero sum game. What do the banks want? It is very easy: the banks want the American taxpayer to take up those losses. If I were a banker, I would want it too. No one likes to bear the losses or consequences of their mistakes. They are trying, in one surreptitious way or another, one non-transparent way or another, to force those losses onto the American taxpayer. The irony is that a lack of transparency got us into this mess, and now some people are trying to use a lack of transparency to get us out of this mess. 
An example of a non-transparent way of doing this is to insure the losses. You take a bundle of toxic assets, and you say, I will insure the loss. But that does not make the loss go away: it just puts the loss onto the balance sheet of the United States Government. However, there is a difference between the accounting frameworks. Moving the losses off the bank's balance sheet shows up as a gain to the bank, so it looks better. However, the United States Government does not keep its books in a way that shows the expected losses, as the losses are not recorded until they occur. We can all go through the fantasy of saying, look, we solved the problem, but only because we were being non-transparent. It is a good trick, but it does not solve the problem because in a few years' time the national debt of the United States is going to be larger, possibly much larger.

In fact, it is worse than a zero sum game, it is a negative sum game. If you do not get incentives right, you get bad behaviour, and part of the problem of the financial sector is that incentives have consistently been bad. As the United States was pouring money into the banks, and the banks were taking money out in bonuses and paying dividends, people looked at this behaviour and said: are these bankers not terrible? Everybody says, yes, American bankers are ethically challenged. That may be true. However, the main problem is that they were responding to perverse incentives, just as earlier they responded to incentives which encouraged them to act in a short-sighted way and engage in excessive risk-taking. In both instances, they behaved in the way that incentives drove them. In fact, I was worried as I looked at the behaviour of the banks in the years leading up to this crisis, because I believed very strongly that we should be seeing serious problems. When we did not see those problems, I worried that my theory was wrong. But the problems that were predicted have now become manifest.

The insurance scheme also gives rise to perverse incentives. The losses of Citibank, for instance, have been insured. They pick up 10 per cent of the loss, and the Government picks up 90 per cent. Mortgages are a key part of the problem, and they ought to be resolved. Even if a house is "underwater", meaning that the value of the mortgage is much greater than the value of the house, it would be better for everybody if people got to stay in their homes. It does no one any good to throw people out of their homes: the house gets wrecked, and the community is weakened. Millions of Americans are losing their homes, and with their homes their life savings. The United States has a social problem, not just an economic problem.

We need to do something about this, but the provision of insurance to the banks against losses makes it even worse. For example, take a mortgage that ought to be resolved. There is a small probability that the price of the house goes up. If it is not resolved and the price goes up, Citibank gets to keep the gain. If the price goes down, which is very likely, the American taxpayer bears the loss. It is a heads-I-win, tails-you-lose situation. This has created a situation where banks have an incentive not to resolve these mortgages and to engage in excessive risk-taking behaviour. It has created asymmetric incentives. That is why this is a negative sum game. 
More broadly, the United States Government has provided most of the capital for several of the major banks, but it does not have control of decisionmaking in these banks. This is true not only in the United States but also in other countries - wherever there is a disparity between who provides the capital and who is making the decisions, there are perverse incentives. These are the first laws of economics. Perverse incentives produce bad behaviour, which destroys wealth. In other words, these countries have created incentives for wealth destruction rather than wealth creation.

These budget deficits will have long-term effects. A few years ago, President Bush said to the American people: "We have a problem. Our social security (which is America's old-age public pension programme) is broken. If we do not do something about it, we will have to break the covenant, the social contract. It will also break our economy." At that time, the size of the deficit in social security - known as the 75-year deficit - was about US\$560 billion. For less than what was spent on bailing out the sick banks, which are still sick, the United States' social security system could have been put on a sound financial basis for generations to come. All the retirees for the next 75 years could have been told that they do not have to worry about their retirement. Now President Obama is also saying that social security has to be re-examined because the funds are not available.

Resources are limited - which is the subject of economics - so choices must be made about how to use those limited resources. Some poor choices have been made in how to bail out ailing banks. And those choices have social and economic consequences, one of which is that there will be elderly people whose retirement benefits will be put in jeopardy.

\section{Concluding remarks}

As we approach the problems posed by the current crisis, it is imperative to keep in mind the importance of maintaining the automatic stabilizers and the social protections. For a robust and sustained recovery, we must also address the underlying problem of insufficiency of aggregate demand, caused by global inequality as well as inequality within countries, and the build-up of excessive reserves, which is related to the global imbalances that have been a cause of growing concern in recent years. Unless the problems in developing countries are addressed in a more effective way than they have been in the past, the inequality will increase and the demand for excessive reserves will grow even greater.

We have to have a better way of managing global risks - including a new global reserve system to replace the dollar reserve system, which is fraying. While we all work hard to fix the problems and reform the regulatory system, we have to recognize that these actions only fix the plumbing. Of course, it is important to have good plumbing. However, if we do not address these more fundamental problems, we will not be able to restore our global economy to sustainable, robust and equitable growth. 